\title{
THE EFFECT OF SUBTITLED ANIMATED CARTOON VIDEOS ON STUDENTS' READING COMPREHENSION \\ (A Quasi Experimental Study at The Sixth Grade Students of SDIT Al- Hasanah Kota Bengkulu)
}

\author{
Gustian Pelani \\ University of Bengkulu \\ Email : goest14n@gmail.com
}

\begin{abstract}
This study aims to investigate whether or not the use of subtitled animated cartoon videos affect students' reading comprehension and to find out in what performance of reading comprehension aspectsthe experimental and control class differ. The population included all the sixth grade students of SDIT Al Hasanah Kota Bengkulu in academic year 2015/2016, which consisted of 77 students. The samples were 52 students that were taken from two classes. The experimental class received a treatment by using animated cartoon videos with bimodal subtitles, while the control class was taught by using animated cartoon videos without subtitles. A pre-test was given to both classes before treatment. The data were analyzed by using SPSS 16 for t-test formula. The results show that, firstly, there was a statistically significant difference between the groups in reading comprehension scores.Therefore, it was concluded that the use of subtitled animated cartoon videos could improve students' reading comprehension. Secondly, for reading comprehension aspects, the experimental class and the control class were different in the literal performance aspect. However, in the inference performance, it showed no significant difference. Based on the results, it wasrecommended to use subtitled animated cartoon videos as the teaching aidin teaching reading comprehension.
\end{abstract}

\section{Keywords: Reading Comprehension, Subtitles, Cartoon Video.}

\section{INTRODUCTION}

Learning English lately has experienced increasing challenges and pressure along with the development of advances in science and technology. Students are not only expected to master the language only of cognitive competence, but more than that they are expected to master the language skills of the communicative competence. English in Indonesia have started to be taught to young children since the age of early elementary school up to college.

However, the focus of education in Indonesia more emphasis on cognitive domains so that most of the students can master a foreign language only from the theoritical aspect, but from the competence of language skillssuch as listening, speaking, reading and writing, their abilitiestends to be very low. It was based on the researcher's observation as the teacher in the school for years that the students' English performance test scores still showed unsatisfied results especially for the reading comprehension.

Teachers have a major role in the efforts to improve students' language skills. Various techniques or methods have been developed and researched by many experts and practitioner of education to improve 
and enhance the quality of education especially teaching and learning process in the classroom, ranging from things that are theoretical up to the things that are more practical or applied knowledge.

The advances in science and technology also have an important role in the efforts of teachers to facilitate the delivery of language knowledge and skills by facilitating them with a variety of technology-based learning resources especially multi-media or applications that can be used in language teaching and learning process in the classroom.

The use of media especially technology indeed is not something new, in fact it has become part of the daily activity both for teachers and students and the community in general. Various media technology commonly brought into the classroom as a tool to improve the quality of learning in the classroom including OHP, LCD projector, videos casette recorders (VCRS), internet, mobile phone, videos, mp3, and so on.

Recently, new advance in technology has brought some innovations, especially for teaching and learning process. One of the tool that can help teachers to present his/her lesson as well as for the students to facilitate them to absorb and acquire language learning is through multimedia.

Many researchers have asserted that the use of authentic materials, implementation of using videos in class, advantages of showing animated cartoon with English subtitles and empirical studies have a great effect on learners' motivation (Fast, 2010; King, 2002 and MacGilivray, 2005).
Moreover, many researchers have presented strong evidence that multimedia have positive effects on language learning as it can provide rich and authentic comprehensible input (Hsu; 2013).

One of the learning resources easily obtained and applied in the classroom including audio-visual media is subtitled animated cartoon videos. According to Danan (2004), audiovisual materials enhanced with captions or subtitles may function as a powerful educational tool in many ways. For example, 1) facilitate language learning by helping students visualize what they hear and 2) increase language comprehension and lead to additional cognitive benefits, such as greater depth of processing (p.67).

In general, the results of research related to the use of subtitled video showed positive results in helping to facilitate teachers to enhance classroom teaching process such as research conducted by Karakas and Saricoban (2010) and Hsu, Hwang, Chang, Y.\& Chang, C. K. Hsu (2013).

Based on the results of these studies, researchers took the same topic to explore further and at the same time to identify how if this research is applied in Indonesia. As the fact, in Indonesia, teaching English to primary schools is not a compulsory subject, but it is a subject that is a local content such as in SDIT Al Hasanah where the researcher teaches as an English teacher.

Then too, similar research more widely applied in more developed countries such as in Taiwan, Turkey, Iran and Malaysia. Most of the research have been done in those 
countries which applying multimedia especially subtitles have showed positive effects in facilitating the students to acquire foreign language.

By conducting this research, the researcher would identify whether this study will also have a positive effects so that it can be applied in Indonesia. Furthermore, from previous studies, there was still very few researchers conducted the similar topicin primary level especially in elementary school. Thus, more research related to this topic should be done especially in elementary level to explore further about the results for future research reference.

In addition, from the previous studies, most of them merely examined one aspect of language such as vocabulary, listening, or reading as a single variable. There are very few research with similar topic conducted in elementary school with more than one language aspect for example studied by Hsu (2013) which conducted in Cram School. In this case, researchers will test two independent variables and this research will be conducted in a formal school in Bengkulu city.

It is hoped from this study, it will be able to enhance the quality of English language teaching process especially teaching and learning process in classroom, especially in order to facilitate students with more authentic learning resources as well as interesting audio-visual equipment. In addition, with this study, it is expected that the students will get more enthusiasm and motivated to learn so that it can improve their language skills, especially broaden their vocabulary knowledge as well as improve their reading comprehension as these two language aspects are two things inextricably linked to each other.

Based on the description above the writer conducts a research untitled "The Effect of SubtitledAnimated Cartoon Video on Students' Reading Comprehension atSDIT Al-Hasanah Bengkulu in 2015/2016 Academic Year".

\section{METHOD}

This research applied a quasi-experimental method. The study aims to investigate whether or not, the use of subtitled animated cartoon videos affect students' reading comprehension and to find out in what performance of reading comprehension aspects that the experimental and the control class differ.

The population included all the sixth grade students of SDIT Al Hasanah Kota Bengkulu in academic year 2015/2016, which consisted of 77 students. The samples were 52 students that were taken from two classes. The experimental class received a treatment by using animated cartoon videos with bimodal subtitles, while the control class was taught by using animated cartoon videos without subtitles.

A pre-test was given to both classes before treatment. The research was done for six meetings and at the end of the sixth meeting, the post-test was distributed. The data were analyzed by using SPSS 16 for ttest formula. 


\section{FINDINGS AND DISCUSSION}

The overall pre-test reading comprehension results can be seen in table1 below:

Table 1: Overall Pre-test Results of Reading Comprehension and Vocabulary Mastery

\begin{tabular}{|c|c|c|c|c|c|c|c|c|c|c|c|c|}
\hline \multirow[t]{2}{*}{ Pre-test } & \multicolumn{2}{|c|}{$\begin{array}{l}\text { Max } \\
\text { Score }\end{array}$} & \multicolumn{2}{|c|}{$\begin{array}{l}\text { Min } \\
\text { Score }\end{array}$} & \multicolumn{2}{|c|}{ Mean } & \multicolumn{2}{|c|}{$\begin{array}{l}\text { Standard } \\
\text { Deviation }\end{array}$} & \multirow[t]{2}{*}{ t-count } & \multirow[t]{2}{*}{$\begin{array}{c}\mathrm{t}- \\
\text { table }\end{array}$} & \multirow[t]{2}{*}{ Diff } & \multirow[t]{2}{*}{ Sig } \\
\hline & $\mathbf{E}$ & C & $\mathbf{E}$ & C & $\mathbf{E}$ & $\mathrm{C}$ & $\mathbf{E}$ & C & & & & \\
\hline $\begin{array}{l}\text { Reading } \\
\text { Comprehension }\end{array}$ & 8 & 9 & 2.5 & 2.5 & 5.67 & 5.56 & 1.27 & 1.66 & 0.047 & 2.01 & $\mathrm{Tc}<\mathrm{Tt}$ & Not Sig \\
\hline Literal aspect & 9.2 & 10 & 2.3 & 3.1 & 6.13 & 6.16 & 1.63 & 1.75 & -0.057 & 2.01 & $\mathrm{Tc}<\mathrm{Tt}$ & Not Sig \\
\hline $\begin{array}{l}\text { Inference } \\
\text { aspect }\end{array}$ & 7.1 & 7.1 & 2.9 & 1.4 & 4.57 & 4.45 & 1.12 & 1.66 & 0.293 & 2.01 & $\mathrm{Tc}<\mathrm{Tt}$ & Not Sig \\
\hline
\end{tabular}

\section{Note:}

$\begin{array}{llll}\mathrm{E} & =\text { Experimental Class } & \mathrm{Tt} & =\mathrm{t}-\text { table } \\ \mathrm{C} & =\text { Control Class } & \text { Diff } & =\text { Difference } \\ \mathrm{Tc} & =\mathrm{t}-\mathrm{count} & \mathrm{Sig} & =\text { Significance }\end{array}$

From the table 1 above, it can be seen the highest score of reading comprehension of the experimental class was 8 and the lowest score was 2.5. Meanwhile, in the control class the highest score was 90 and the lowest was 2.5 .

From the calculation of reading comprehension scores result before treatment between the experimental class and the control class can be seen from pretest result of t-test of this research, and the result was 0.047 .

The result of t-table is 2.01 , it can be seen from significant degree or $\alpha$ (alpha) $=$
0.05 and df 50. Ho is accepted, and the $\mathrm{H}_{1}$ is rejected because $0.047<2.01$ or the t-test $<\mathrm{t}$-table. It can be concluded that there is no significant difference of students' reading score between the experimental class and the control class before treatment.

For literal scores, the highest score of the experimental class was 9.2 and the lowest score was 2.3. Meanwhile, in the control class the maximal score was 10 and the minimal score was 3.1. From the calculation, it was found that the mean score of experimental class was 6.13 and control class was 6.16. Experimental class 
means score was bigger than control class. From t-test calculation, the value of t-count was 0.057 and t-table was 2.01. It showed that $\mathrm{t}$ obtained was smaller than $\mathrm{t}$ table ( $\mathrm{t}$ count $<$ t-table; $0.057<2.01)$. Based on the explanation above, the differences between the two groups were small or not significant. Briefly, these two classes have similar ability.

For the inference score of the pre-test, we can see from the table that the maximal score of the experimental class was 7.1 and the minimal score was2.9. Meanwhile, in the control class the maximal score was also 7.1 and the minimal score was 1.4.

From the calculation, it was found that the mean score of experimental class was
4.57 and control class was 4.45, the experimental class means score was bigger than control class. From t-test calculation, the value of t-count was 0.293 and t-table was 2.01 .

It showed that $\mathrm{t}$ obtained was smaller than $\mathrm{t}$ table ( $\mathrm{t}$-count $<\mathrm{t}$-table; $0.293<2.01$ ). Based on the explanation above, the differences between the two groups were small or not significant. Briefly, these two classes have similar ability.

Secondly, for the overall post-test reading comprehension and vocabulary mastery results can be seen on the following table 2 below:

Table 2: Overall Post-test Results of Reading Comprehension and Vocabulary Mastery

\begin{tabular}{|c|c|c|c|c|c|c|c|c|c|c|c|c|}
\hline \multirow[t]{2}{*}{ Post-test } & \multicolumn{2}{|c|}{$\begin{array}{l}\text { Max } \\
\text { Score }\end{array}$} & \multicolumn{2}{|c|}{$\begin{array}{l}\text { Min } \\
\text { Score }\end{array}$} & \multicolumn{2}{|c|}{ Mean } & \multicolumn{2}{|c|}{$\begin{array}{l}\text { Standard } \\
\text { Deviation }\end{array}$} & \multirow{2}{*}{$\begin{array}{c}\mathbf{t}- \\
\text { coun } \\
\mathbf{t}\end{array}$} & \multirow[t]{2}{*}{$\begin{array}{c}\text { t- } \\
\text { table }\end{array}$} & \multirow[t]{2}{*}{ Diff } & \multirow[t]{2}{*}{ Sig } \\
\hline & $\mathbf{E}$ & C & $\mathbf{E}$ & $\mathbf{C}$ & $\mathbf{E}$ & $\mathbf{C}$ & $\mathbf{E}$ & C & & & & \\
\hline $\begin{array}{l}\text { Reading } \\
\text { Comprehension }\end{array}$ & 9.5 & 10 & 3.5 & 3.5 & 7.10 & 6.02 & 1.42 & 1.88 & 2.327 & 2.01 & $\mathrm{Tc}>\mathrm{Tt}$ & Sig \\
\hline Literal aspect & 10 & 10 & 3.8 & 3.8 & 8.11 & 6.92 & 1.63 & 2.04 & 2.329 & 2.01 & $\mathrm{Tc}>\mathrm{Tt}$ & Sig \\
\hline Inference aspect & 8.6 & 10 & 2.9 & 1.4 & 5.16 & 4.56 & 1.44 & 1.84 & 1.309 & 2.01 & $\mathrm{Tc}<\mathrm{Tt}$ & $\begin{array}{l}\text { Not } \\
\text { Sig }\end{array}$ \\
\hline
\end{tabular}

\section{Note:}

$\mathrm{E} \quad=$ Experimental Class

$\mathrm{Tt} \quad=\mathrm{t}$-table

$\mathrm{C}=$ Control Class

Diff $\quad=$ difference

$\mathrm{Tc} \quad=\mathrm{t}$-count

Sig = significance

From the table 2, firstly, for reading highest score of the experimental class was comprehension score, it can be seen that the 9.5 and and the lowest score was 3.5. 
Meanwhile, in the control class the highest score was 10 and the lowest was 3.5. From the Table 6, the calculation of reading comprehension result before and after treatment for control class can be seen from pre-test and post-test result of t-test of this research, and the result is 2.327 .

The result of t-table is 2.009 , it can be seen from significant degree or $\alpha$ (alpha) $=$ 0.05 and $\mathrm{df}=50\}$. Ho is rejected, and the $\mathrm{H}_{1}$ is accepted because $2.327>2.01$ or the t-test $>$ t-table. It can be concluded that there is a significant difference on students' reading comprehension scorein the experimental class after treatment.

For literal aspect, we can see that in the experimental class, maximal score was 10 , while minimal score was 3.8. Meanwhile, in the control class, maximal score was also 10 and minimal score was also 3.8. From the calculation, it was found that mean score of experimental class was 8.11 and the mean score of control class was 6.92 .

From the t-test calculation, t-count was 2.329 and t-table 2.01. It shown that t-count was bigger than t-table $(2.329>2.01)$. It can be concluded that $\mathrm{H}_{0}$ was rejected and $\mathrm{H}_{1}$ was accepted. In other words, there was a significant difference in literal post-test score average between the experimental class and the control class. Shortly, it showed that this strategy could improve students' literal aspect of reading comprehension.

For inference performance of the posttest, as we can see from the table, the maximal score of experimental class was 8.6, while the minimal score was 2.9 .
Meanwhile, in the control class, maximal score was 10 and minimal score was also 1.4. From the calculation, it was found that mean score of experimental class was 5.16 and the mean score of control class was 4.56. From the t-test calculation, t-count was 1.309 and t-table 2.01. It showed that t-count was smaller than t-table $(1.309<2.01)$.

It can be concluded that $\mathrm{H}_{0}$ was accepted and $\mathrm{H}_{1}$ was rejected. In other words, there was no significant difference in inference post-test score average between the experimental class and the control class for inference aspect. Shortly, it shows that this media could not improve students' inference aspect of reading comprehension.

In order to analyze the total of pre-test and post-test results, the total score of the experimental and control class were compared by using t-test. The statistical program of SPSS was used independent samples t-test was run to calculate the significance of the difference between the scores in the pre-test and the post-test. After comparing the results of the pre-test and the post-test, this research have answered each point of research questions.

Firstly, for the first research question, whether or not the use of subtitled animated cartoon video can improve reading comprehension, as the result of this research, the use of subtitled animated cartoon videos could improve reading comprehension of the sixth grade students of SDIT Al Hasanah Bengkulu City. In the post-test, the mean of reading comprehension score of the experimental class was significantly different to the 
control class. This findings were in line with the studies conducted by Chen (2011), Etemadi (2012) and Su (2015). Thus, this research findings support the theories as stated by Canning (2000:1), "Video is the selection and sequence of messages in audio-visual context". It helps to represent the text in visual form. Itcan also make the viewers easy to understand the message delivered by visualclues provided in the video.

By watching the video, the students can see facialexpressions, gestures, postures, and details of the environment, etc. Lonergan (1995:5) says that the learners will be eager to watch, even if their comprehensionis limited. It means that the learners will still watch the video although they getdifficulty in comprehending the text. Therefore, by using cartoon video inteaching reading skill, the students can easily get the idea by synchronizing whatthey read and what they watch.

Moreover, at the beginning of the treatment, the researcher focused on introducing the steps in applying the treatments using the videos. Most students seemed to find difficulty in understanding the contents of videos sincethey often used Indonesian subtitles while watching videos.

While in this research, the students were guided to the meaning of difficult words by using bimodal (English) subtitles. As Stewart and Pertusa (2004) hypothesized that films subtitled in the target language are more appropriate foreign language learning tools for English learners although most English instructors use English subtitled films in foreign language classes.
They avow that one of the biggest drawbacks for English subtitling is the neglect of the listening skill. Using subtitled animated cartoon videos also provide all students the suitable visual stimulus which can generate predictions and reflections, and give teachers a chance to activate students' background knowledge. (Oddone, 2011:105).

It also gives chance for the students to be active and take their role in the learning process in practice reading comprehension and acquiring vocabulary. Therefore, all of students were free to learn and had a chance to practice their reading comprehension.

\section{CONCLUSION AND SUGGESTION}

Having completed the research of using subtitled animated cartoon videos in teaching reading comprehension and vocabulary mastery at the sixth grade students of SDIT Al Hasanah Kota Bengkulu.

The conclusions of this research were described as follows; Firstly, the use of subtitled animated cartoon was effective to improve students' reading comprehension scores than using videos without subtitles. Secondly, in the use of this media could improve students' performance in literal aspect. While in inference aspect, the use of this media was not effective.

Based on the conclusion above, the writer would like to give some suggestions related to this research, which hopefully will be helpful for English teacher, students, institution, and further researcher. For English teacher, stimulate the students to be 
active in the teaching learning process is very important.

Teachers should motivate and challenge them to read and acquiring vocabulary more effectively in teaching and learning process. Based on that reason, the language teachers should choose a certain teaching medias that can build a good atmosphere of teaching learning process such as using subtitiled animated cartoon videos.

For the students, a great motivation is something that students should have. With a great motivation, they will practice more in order to explore their English. They also should practice the reading comprehension more, because it can give more knowledge for them.

Reading also can enrich their vocabulary. Subtitled animated cartoon videos is an effective media that can be used for improving students' reading comprehension. Through subtitled animated cartoon videos, the students be an active readers since they are interested with the teaching media, also they can understand the content better by using the teaching media.

\section{REFERENCES}

Alderson, J. C. (2000). Assessing reading. Cambridge: Cambridge University Press.

Anderson, N. J., \& Nunan, D. (2003). Practical English language teaching. (pp.67-86). New York: McGraw-Hill.

Arikunto, S. (2006). Prosedur penelitian.Jakarta:PT RinekaCipta.

Arsyad, A. (2008). Media pembelajaran_Jakarta: PT. Rajagrafindo Persada.
Ary, D,. (1985). Introduction to Research in Education, $3^{\text {th }}$ edition, Noterm Illinois University.

Baltova, I. (1999). The effect of subtitled and staged video input on the learning and retention of content and vocabulary (Doctoral dissertation, University of Toronto).

Best, J. W. (1981). Research in education. USA:Prentice-Hall, Inc.

Brown, H. D. (2004). Language assessment: Principles and classroom practices. New York. Pearson Education.

Brown, H.D, Principles of language learning and teaching $\left(5^{\text {th }} \mathrm{Ed}\right)$.New York.Pearson Education, Inc.

Canning-Wilson, C., \& Wallace, J. (2000). Practical aspects of using video in foreign language classroom. The Intemet TESL Journal, 6(11), 361.

Celce-Murcia, M., \& McIntosh, L. (1991). Teaching English as a second or foreign language. Washington: Heinle and Heinle Thomas Leaming Inc.

Celce-Murcia, M., \& Olshtain, E. (2000). Discourse and context in language teaching: A guide for language teachers. USA: The Press Syndicate of the University of Cambridge.

Chen, G. Y., \& Pholsward, R. (2011). The use of subtitled English cartoon movies to support reading comprehension of Chinese elementary school students.

Daryanto, D. (2010). Media Pembelajaran. Yogyakarta: Gava Media.

Djamarah, S. B., \& Zain, A. (2006). Strategi belajar mengajar. Jakarta:PT.Rineka Cipta.

Djiwandono, M. S. (1996). Tes bahasa dalam pengajaran. Bandung: ITB Bandung.

Djiwandono, P. I. (2009). Strategi Belajar Bahasa Inggris. Indonesia: PT Malta Pratindo. 
Douglas, D. A. N., \& Frazier, S. (2001). Teaching by Principles: An Interactive Approach to Language Pedagogy, USA:Addison Wesley Longman, Inc.

Duke, N.K. (2003). Comprehension difficulties. CIERA, 11. Retrieved on August $25^{\text {th }}, 2015$ from www.ciera.org/ibrary/presos/2003/.

Etemadi, A. (2012). Effects of bimodal subtitling of English movies on content comprehension and vocabulary recognition. International journal of English linguistics, 2(1), 239.

Gorjian, B. (2014). The effect of movie subtiting on incidental vocabulary learning among EFL learners. International Joumal of Asian Social Science, 4(9), 1013-1026.

Grabe, W. P., \& Stoller, F. L. (2002). Teaching and researching reading. Essesx: PearsonEducation.

Grellet, F. (1981). Developing reading skills: A practical guide to reading comprehension exercises. Cambridge: Cambridge University Press.

Harji, M. B., Woods, P. C., \& Alavi, Z. K. (2010). The effect of viewing subtitled videos on vocabulary leaming. Journal of College Teaching and Leaming, 7(9), 37.

Harmer, J. (1991). The practice of English language teaching. UK: Longman Group.

Harmer, J. (1998). How to teach English: An introduction to the practice of English language teaching. Edinburgh: Addison Wesley Longman.

Haris, D. P. (1969). Testing English as a Second Language. New York: Mc. Graw-Hill, Inc.

Heaton, J. B. (1988). Writing English Language Test. Longman Group Ltd.

Hornby, A. S. (2003). Oxford Leamer's Pocket Dictionary. New York: OxfordUniversity Press.

Hsu, C. K., Hwang, G. J., Chang, Y. T., \& Chang, C. K. (2013). Effects of Video Caption Modes on English Listening Comprehension and
Vocabulary Acquisition Using Handheld Devices. Educational Technology \& Society, 16(1), 403-414.

Ismaili, M. (2013). The effectiveness of using movies in the EFL classroom-a study conducted at south east European university.Academic Journal of Interdisciplinary Studies, 2(4), 121.

Janette, K. K., Vaughn, S., \& Boardman, A. (2007). Teaching Reading Comprehension to Students with Learning Difficulties.New York: The Guidford Press.

Johnson, A. P. (2008). Teaching reading and writing: A guidebook for tutoring and remediating students. USA: R\&LEducation.

Judickaite-Pašvenskienè, L. (2013). Subtitled Cartoons in Foreign Language Teaching and Learning Context: Dangers. Darnioji daugiakalbyste, (2), $161-172$.

Karakas, A., \& Sariçoban, A. (2012). The impact of watching subtitled animated cartoons on incidental vocabulary learning of ELT students. Teaching English with Technology, (4), 3-15.

Macgillivray, I. K. (2005). Using cartoons to teach students about stereotypes and discrimination: One teacher's lessons from South Park. Journal of Curriculum and Pedagogy, 2(1), 133-147.

Mikulecky, B. S., \& Jeffries, L. (2007). Advanced reading power: extensive reading, vocabulary building, comprehension skills, reading faster. New York: Addison Wesley Publishing Company.

Munir, F. (2016).The Effectiveness of Teaching Vocabulary by Using Cartoon Film toward Vocabulary Mastery of EFL Students. Journal of English Language Teaching and Linguistics, 1(1), 13-37.

Nagy, W. E. (1988). Teaching vocabulary to improve reading comprehension. National Council of 
Teachers of English, 1111 Kenyon Rd., Urbana, IL61801.

Nation, I. S.P.(2008). Teaching ESL/EFL reading and writing. New York and London: Routledge Taylor and Francis Group.

Nunan, D.(1991). Language Teaching Methodology. New York: Prentice Hall International (UK) Ltd.

Pang, E. S., Muaka, A., Bemhardt, E. B., \& Kamil, M. L. (2003). Teaching reading. Geneva: International Bureau of Education.

Reich, P., (2006). The film and the book in translation. MA thesis. Masaryk University. (Accessed April 21, 2009). Available from: http://is.muni.cz/th/64544/ff_mm/Diplomova prace.

Richards, C.J and Renandya, A. W. (2002).Methodology in language teaching : an anthology of current practice. Cambridge: Cambridge University Press.

Sadiman, S. A. (1986). Media Pendidikan. Jakarta: Rajawali.

Setiyadi, B. (2006). Teaching english as a foreign language. Yogyakarta: Graha llmu.

Sharon, S. E., James, D. R., Robert, H., \& Michael, M. (2002). Instuctional Technology and Media for Leaming. USA: PEARSON

Spratt, M., Pulverness, A., \& Williams, M. (2005). The Teaching Knowledge Test (TKT Course
Book). Cambridge: Cambridge University Test.

Stewart, M.A., \& Pertusa, I (2004). Gains to language learners from viewing target language closedcaptioned films. Foreign language annals, 37(3), 438-442.

Sumadi, S. (2006). Metode penelitian. Jakarta : Rajawali press.Su, S. C., \& Liang, E. (2015). Using Subtitled Animated Cartoons and Textbook-based CDs to Test Elementary Students' English Listening and Reading Comprehension in a Cram School. International Journal of Applied Linguistics and English Literature, 4(1), 106-114.

Sudijono, A. (2006). Pengantar Statistik Pendidikan. Jakarta: PT. Raja Grafindo Persada.

Surapranata, Sumama. 2004. Analysis, Validity, Reliability dan Interpretasi Hasil Tes. Jakarta:Rosda.

Tanzeh, A. (2006). Dasar-Dasar Penelitian. Surabaya: elKAF.

Tanzeh, A. (2009). Pengantar Metode Penelitian. Yogyakarta: Teras.

Westwood, P. S. (2008). What teachers need to know about teaching methods. Camberwell: ACER Press.

Zarei, A. A. (2009). The effect of bimodal, standard, and reversed subtitling on L2 vocabulary recognition and recall. Pazhuhesh-eZabanha-ye Khareji, 49 (1), 65-85. 